\title{
産業用ロボットによるマニピュレーションのための ビューベースト教示再生*
}

森山 祐樹 ${ }^{* 1}$, 前田 雄介 ${ }^{* 2}$

\section{View-Based Teaching/Playback for Manipulation by Industrial Robots}

\author{
Yuki MORIYAMA and Yusuke MAEDA*2 \\ ${ }^{* 2}$ Division of Systems Research, Faculty of Engineering, Yokohama National University \\ Tokiwadai 79-5, Hodogaya-ku, Yokohama 240-8501, Japan
}

\begin{abstract}
The conventional teaching/playback scheme is widely used for robot programming due to its reliablity and general versatility. However, it is applicable only when task conditions does not vary. In this paper, we study a method of robot programming with view-based image processing: view-based teaching/playback. It can adapt to changes of task conditions such as variations in initial pose of the object, without losing the general versatility. The method is composed of two parts: teaching phase and playback phase. In the teaching phase, a human operator commands a robot to perform a manipulation task as a demonstration. Scene images and corresponding robot motions are recorded in the demonstration. A mapping from the images to the robot motions is obtained as a neural network by learning from the demonstration data. In the playback phase, a robot motion is generated by the mapping. We applied this view-based teaching/playback to pushing tasks by an industrial robot. After multiple teaching demonstrations, pushing an object to a goal position was successfully achieved from some initial poses that are not identical to those in the demonstrations. This indicates that our view-based teaching/playback can deal with a certain range of variations in initial pose of the object without object models or camera calibrations.
\end{abstract}

Key Words : Robot, Manipulator, Image Processing, Teaching, View-Based Approach, Principal Component Analysis, Neural Network

\section{1. 序論}

産業用ロボットに作業を行わせるには，あらかじめロボットに行うべき動作・作業内容を教え込む，教示という 作業が必要となる．従来は, 人間が教示した通りに関節変数を忠実に再現するティーチングプレイバック方式が 採用されてきた。しかし，この教示手法では作業条件（例えば対象物の初期位置か変わるなど）が教示時と変わ らなければ動作が確実であるが，一方で，作業条件が教示時と変わると作業が実行できないという問題点がある．

作業条件の変化に対応するには外界センサによるフィードバックの導入が必要であり，特に情報量の大きい視覚 情報を用いることが有用であると考えられる．視覚センサによる環境認識方法には, 事前に用意されたモデルと 入力特徵との照合に幾何学的な特徵を利用するモデルベーストアプローチと，特徵抽出をせず画像データを高の まま用いるビューベーストアプローチという手法がある ${ }^{(1)}$. モデルベーストアプローチは対象物の位置・姿勢が明 示的にわかるため幅広く用いられているが, 物体に合わせて照合対象となるモデルをあらかじめ構築しなければ ならないという手間がある.また, 事前にカメラのキャリブレーションを行わなければならない.一方，ビュー ベーストアプローチは画像データを弚のまま用いるため対象物に特化した処理が必要なく, 手法としての汎用性 が期待できる .

*原稿受付 2013 年 4 月 12 日

*1 キヤノン(株)

*2 正員, 横浜国立大学院工学研究院システムの創生部門（テ240-8501 神奈川県横浜市保土ヶ谷区常盤台 79-5）

E-mail: maeda@ynu.ac.jp 


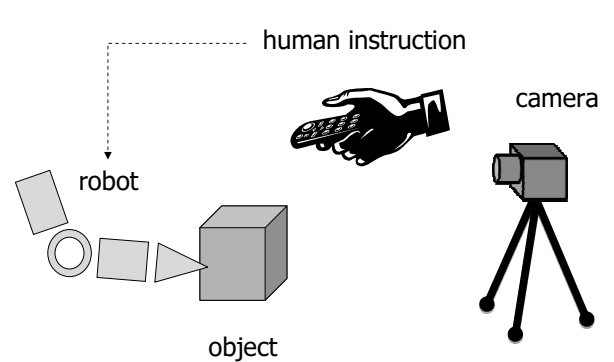

(a) teaching by human operator

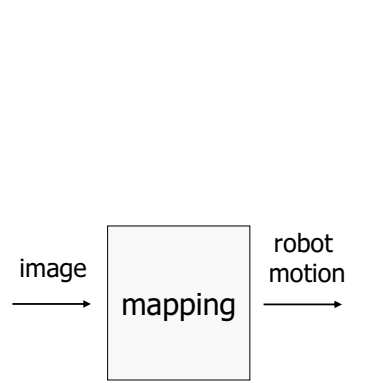

(b) obtaining mapping from image to robot motion

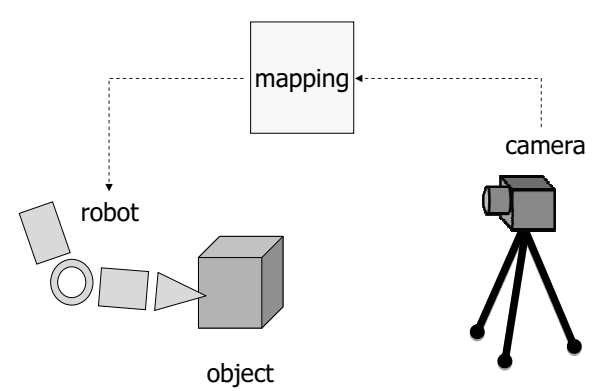

(c) autonomous playback with obtained mapping

Fig. 1 Outline of View-based Teaching/Playback

そこで，筆者らはロボット教示にビューベーストアプローチを用いた「ビューベースト教示再生」を提案して いる ${ }^{(2)}$. 取得画像群に対して主成分分析 (PCA) を行うことで画像データを削減し，ビューベーストアプローチの 欠点を補っている．また，ニューラルネットワークを用いることにより教示時と異なる条件でのマニピュレーショ ンの再生に成功している。しかし，この研究は仮想環境上でのみ行われており，実環境におけるビューベースト教 示再生の検証は行われていない，乥こで，本論文では従来研究 ${ }^{(2)}$ て提案されたビューベースト教示再生の改良を行 い，実環境におけるビューベースト教示再生の確立を目的とする．なお，ここでは作業条件の変化として対象物 の初期位置・姿勢のばらつきを想定し, 弚れにもかかわらず決まった目標位置・姿勢に対象物を搬送できるよう にすることを目指す．

\section{2. 関 連 研 究}

古典的なティーチングプレイバック方式の枠組みを超えて, 人間の動作呈示から樣々な動作を教示することを 目指した Programmming by Demonstration の研究は, 近年盛んに行われている ${ }^{(3)(4)}$. 乥の中には視覚を利用するも のも多いが，ほとんどはモデルベーストアプローチを用いている .

柴田らはビューベーストアプローチとニューラルネットワークを用いて移動ロボットにブロックの押し操作を 強化学習させた ${ }^{(5)}$. また , 小林らは分解能の調節可能な特徵抽出方法を用いてロボットにブロックの押し操作をさ せるビューベースト手法を提案した ${ }^{(6)}$. これらの研究では強化学習による自律的な動作獲得を指向しているため， 作業は比較的簡単なもの（目標位置が存在しない，要求精度が低いなど）にとどまっている．

その他の関連研究としてはビューベーストビジュアルサーボ ${ }^{(7)}$ がある . これらの研究は本手法と類似する点が あるが, これらが対象物に対する相対的な位置決めを扱っているのに対し，本論文の手法は対象物をゴール位置 まで運ぶ゙マニピュレーションである，という点が異なる．

\section{3. ビューベースト 教示再生の概要}

本手法は通常のティーチングプレイバックと同樣に教示フェーズと再生フェーズの二段階に分かれている .

教示フェーズでは , 教示者がロボットを動かすことにより，作業を教示する (図 1(a)) . 教示中のすべての画像 はカメラによって記録され, 光れに対応したロボットの動きも記録される.光して, ニューラルネットワークに より, 記録された画像と光れに対応したロボットの動きとのマッピングが得られる (図 1(b)) . ここで, ニューラ ルネットワークの入力はカメラ画像, 出力は关の画像に対応したロボットの動きである . ここで言う「ロボット の動き」とは， 1 制御周期ごとのロボットの相対運動を指す．弚の具体的な中身は本手法の適用先に依存するが， 例えばハンドの位置・姿勢の変化量などである.

再生フェーズでは, ロボットの動きをカメラ画像から計算されたニューラルネットワークの出力によって決定 する (図 1(c)) .もしニューラルネットワークが適切に機能したなら , 作業状況が変わらない限り教示フェーズの ロボットの動きが再現される．さらに，作業条件が変化したとしても（例えば対象物の初期位置が変わるなど）, ニューラルネットワークの汎化能力によってロボットに作業を実行させることができる可能性がある . 


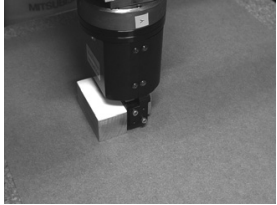

(a) original

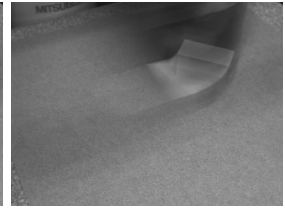

(b) average

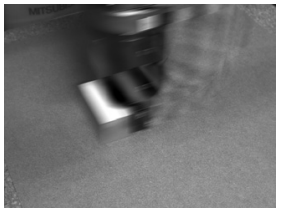

(c) w/ 10 eigenvectors

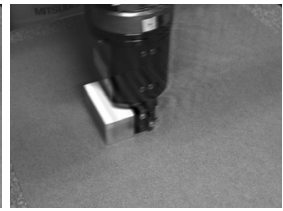

(d) w/ 30 eigenvectors

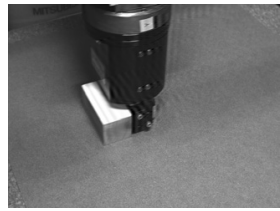

(e) w/ 50 eigenvectors
Fig. 2 Reproduced Image

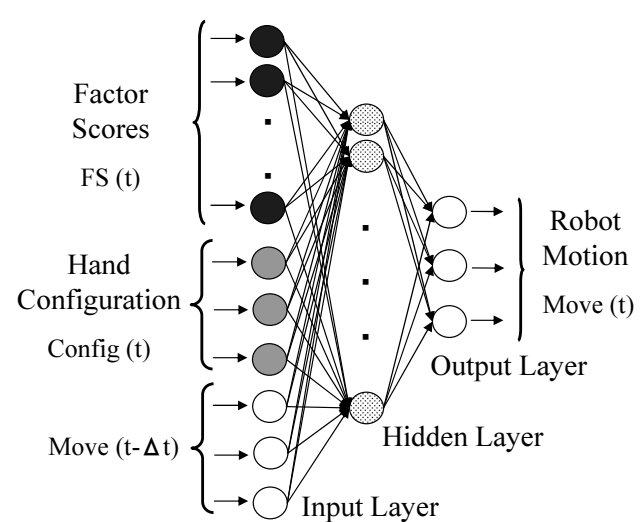

Fig. 3 Neural Network for Robot Motion

4. 教 示フェーズ

$4 \cdot 1$ 教示者による教示

教示フェーズでは , 教示者がティーチングペンダントのような入カデバイスを用いてロボットを動かすことに より作業を教示する．ここで, カメラ画像と光れに対応したロボットの動きか教示中に記録されている．

教示時と作業条件が全く変わらない場合は 1 回の教示でもよいが, 弚れならば通常のティーチングプレイバック でよい. 光こで, ニューラルネットワークの汎化能力を利用するために , 教示時とは異なる状況で 2 回以上の教 示を行う．

\section{$4 \cdot 2$ 主成分分析による画像圧縮}

カメラ画像は膨大なピクセルデータを有しているので , ニューラルネットワークの入力として生のピクセルデー 夕を用いるのは現実的ではない．すなわち，画像の圧縮が必要である.

ここでは, Zhang らの手法 ${ }^{(7)}$ と同樣に，画像の圧縮のために，教示時の全画像に対して主成分分析を行う. 少数 の上位主成分によって得られる主成分スコアから元画像を再構成できるので (図 2)，生のピクセルデータの代わ りに主成分スコアをニューラルネットワークの入カとして用いることにする．

本手法では主成分を得る計算負荷を低減させるために Turk らの手法 ${ }^{(9)}$ を用いることにする .

\section{$4 \cdot 3$ ニューラルネットワークによるマッピング}

カメラ画像と光れに対応したロボットの動きをマッピングするために図 3 に示すような三層型のフィードフォ ワード型のニューラルネットワークを用いる .このニューラルネットワークは出カがロボットの動き $(\mathrm{Move}(t))$, 入力が現在画像の主成分スコア $(\mathrm{FS}(t))$ ，光の時のロボットのハンドのコンフィグレーション $(\mathrm{Config}(t)), 1 \mathrm{step}$ 前 のロボットの動き $(\operatorname{Move}(t-\Delta t))$ であり, 次のような関数として書ける .

$$
\operatorname{Move}(t)=f(\operatorname{FS}(t), \operatorname{Config}(t), \operatorname{Move}(t-\Delta t))
$$

ここで, $\Delta t$ はサンプリング周期である．Move $(t), \operatorname{Config}(t)$ の中身は本手法の適用先に依存するが，例えば後者は ハンドの位置・姿勢, 前者は谷の変化量などとなる .

入力には現在画像の主成分スコアの他に，ロボットのハンドの現在のコンフィグレーションの情報を追加してい る . ハンドの現在のコンフィギュレーションの情報は, カメラ画像にも暗に含まれているので必ずしも必要ではな い.しかし, 内界センサからより正確な情報が得られること，また，カメラ画像に写るハンドがオクルージョン の状態にある場合やカメラ画像にハンドが写っていない場合には, 主成分スコアからはハンドの情報が得られな いことから , 入力に加えている . 1 step 前のロボットの動きを入力に加えているのは, リカレントニューラルネッ トワークの構造をとることで, 作業の前後関係を認識できるようにするためである .つまり，カメラ画像とハン ドのコンフィギュレーションが変化しなくても，1 step 前のロボットの動きによって出力を変えることが可能にな る .これはロボットの動きの切り替え（例えば，接近からピッキングへの切り替えなど）に役立つ． 
マッピングの学習に用いる教示データの出力には大きな飛びが含まれている可能性がある．例えば，教示者が ロボットの動作指令を急激に変えた場合には, ニューラルネットへの入力の教示データの変化量が小さいにもか かわらず, 出力の教示データだけが大きく変化することがありうる .この飛びの中間に対応するデータがニューラ ルネットワークに入力された時にロボットが予期せぬ動きをすることを避けるため, 飛びが大きい箇所に対して 教示データの線形補間を行い, 乥こから作られた人工的な教示データも学習に用いる.なお，ニューラルネット ワークの重みはモーメント法 ${ }^{(10)}$ を用いた誤差逆伝播法 (BPM) により計算される .

\section{5. 再 生 フェーズ}

再生フェーズでは, ロボットの動きをカメラ画像から計算されたニューラルネットワークの出力によって決定す る.ここで, ゴール位置で再生を終わらせる終了条件を定義しなければならない . 本手法はビューベーストであ るため, 対象物の位置・姿勢を使うことはできない．したがって，現在画像と教示終了時の画像の主成分スコア の RMS 誤差を使うことにする . RMS 誤差 $\Delta E_{S}$ は次のように書ける .

$$
\Delta E_{S}=\sqrt{\frac{\sum_{i=1}^{N}\left|\mathrm{FS}(t)_{i}-\mathrm{FS}_{\mathrm{Goal} i}\right|^{2}}{N}}
$$

ここで, $\mathrm{FS}(t)_{i}$ と $\mathrm{FS}_{\mathrm{Goali} i}$ は光れ光れ $i$ 番目の主成分の現在画像とゴール画像 (教示終了時の画像) の主成分スコア であり， $N$ は画像圧縮に用いた主成分数である.なお，取得画像の輝度值は $[0,1]$ の実数值に正規化して扱う. 現 在画像の主成分スコアには暗に対象物の位置・姿勢の情報が含まれていることに注意されたい .

なお，本論文では PCA で求める主成分べクトル $u_{i}$ を正規直交化ベクトルとして算出しているため，式 (2) は次 のように変形できる .

$$
\Delta E_{S}=\sqrt{\frac{\left|\sum_{i=1}^{N}\left(\mathrm{FS}(t)_{i}-\mathrm{FS}_{\mathrm{Goal} i}\right) \boldsymbol{u}_{i}\right|^{2}}{N}}
$$

少数の主成分スコアで画像を復元できることから (4.2 節参照) , 式 (3) は現在とゴール時の近似画像のピクセル 単位での画像比較とほぼ等価であると言える．また，少数の主成分スコアを用いることで，ピクセル単位での画 像比較とほぼ等価な計算を高速で行えるというメリットがある．

対象物の位置情報は以上のように画像から取得しなければならないが，ロボットの位置情報は内界センサから 取得することができる，乥こで，終了条件には，ロボットの位置情報も利用することにする．ロボット上に適当 な参照点を $M$ 個設定し, 弚れらの現在とゴール時のRMS 誤差を求める .

$$
\Delta E_{H}=\sqrt{\frac{\sum_{i=1}^{M}\left|E_{P}(t)_{i}\right|^{2}}{4}}
$$

ここで, $E_{P}(t)_{i}$ は参照点 $i$ の現在からゴール位置までの距離である .これにより，ロボットの位置・姿勢のゴール とのずれを， $\Delta E_{H}$ で表現することができる.

以上より，終了条件を次のように定義できる．

$$
\Delta E_{S}<T_{S} \text { and } \Delta E_{H}<T_{H}
$$

ここで， $T_{S}$ と $T_{H}$ は閾値である。しかし，この式が成立しても，再生を終了せずに動かし続けるとさらに対象物を ゴール位置に近づけられる可能性がある.説明のために，簡単な例として並進のみの終了条件で考える.图 4 に示 すゴール位置に対してマニピュレーションを行う場合, 式(5)の終了条件ではゴール (近傍) 領域の縁まで辿り着 いたら終了条件を満たしたとして再生か終了してしまう．しかし, Routeのような経路をハンドが通る場合, ゴー ル領域の内側に入っても動かし続ければ , ハンドはさらにゴール位置に近づくことができる (図 4) .

このことから，次のような二段階の終了条件を定義する．まず第一段階として，カメラ画像が教示終了時の画 像とほぼ同じで，かつハンド位置・姿勢も教示終了時にかなり近くなったことを確認する (式 (5)) . 次に第二段 階として $\Delta E_{S}(t)>\Delta E_{S}(t-\Delta t)$ となるまで，すなわち $\Delta E_{S}$ が小さくなり続ける限り（現在画像がゴール画像に近づ 〈限り)，再生を続ける．これにより，ゴール領域の縁で停止してしまうことなく，ハンドをゴール位置までさら に近づけられるようにする . 


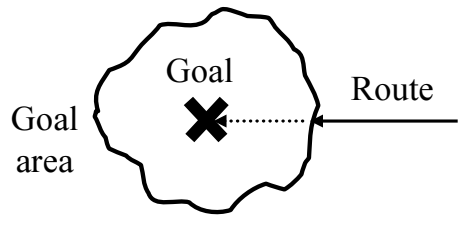

Fig. 4 Improvement of Goal Condition

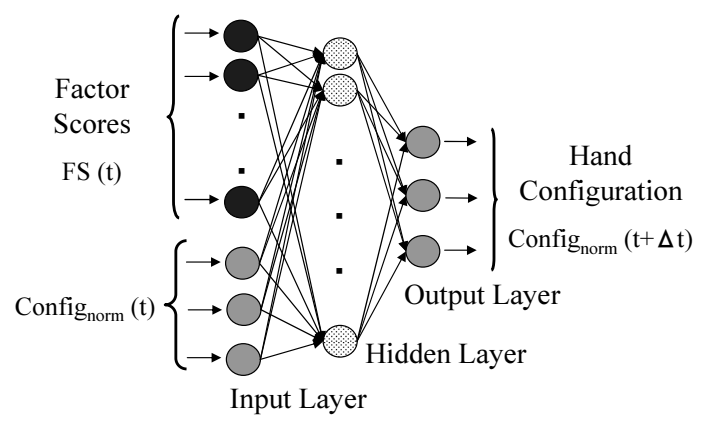

Fig. 5 Neural Network for Abnormality Judgment

\section{6. 異 常 判 定}

再生フェーズにおいて終了条件を満たさない場合，ロボットは動き続けることになるが，大きな外乱などがあっ た場合には，ロボットが予期せぬ挙動を示す恐れがある．光こで，再生フェーズでの異常があった場合は光れを検 知し, 再生を自動で緊急停止させることが可能であることが望ましい. 弚のために, 图 5 に示すニューラルネット ワークを導入する .このニューラルネットワークは出力が 1 step 後のロボットのハンドのコンフィグレーション $\left(\operatorname{Config}_{\mathrm{norm}}(t+\Delta t)\right)$, 入力か現在画像の主成分スコア $(\mathrm{FS}(t))$, 弚の時のロボットのハンドのコンフィグレーション $\left(\right.$ Config $\left._{\text {norm }}(t)\right)$ であり, 次のような関数として書ける .

$$
\operatorname{Config}_{\text {norm }}(t+\Delta t)=g\left(\mathrm{FS}(t), \text { Config }_{\text {norm }}(t)\right)
$$

このニューラルネットワークの重みも，教示フェーズのデータから誤差逆伝播法により計算する .なお， ここで のロボットのハンドのコンフィグレーションは作業環境で取り得る各方向の最大值，最小值を用いて正規化して いる。

図 3 に示したニューラルネットワークは相対座標系を用いているが，図 5 では絶対座標系を用いているといj 違いがある .ここで, ロボット出力用のニューラルネットワーク (図 3) を見ると， 入力の一つであるロボットの ハンドの現在のコンフィグレーションと, 出力のロボットの動きからも異常判定用のニューラルネットワーク (図 5) の出力である 1 step 後のロボットのハンドのコンフィグレーションが算出できる . 光こで , この二つのニュー ラルネットワークから算出できる $1 \mathrm{step}$ 後のロボットのハンドのコンフィグレーションの差を異常判定に用いる . 再生フェーズにおいて特に異常が起きない場合, この差はあまりない．しかし，再生フェーズにおいてロボット が予期せぬ動きをした場合は, 教示フェーズとは異なる状況となるため, この差が徐々に大きくなっていき, こ れによって再生時の異常が検知できる．

\section{7. 押し 操作への応用}

\section{1 実験環境}

図 6 に準備した実験環境を示す。

ロボットには三菱電機製の 6 自由度マニピュレータ RV-1A を用いた . 動作コマンドはイーサネット経由で PC からロボットに送られる .この PC の CPU は Core i7 860 (2.80GHz) で, PCA や BPM のようなオフラインの計算 用にCore i7 $2600(3.40 \mathrm{GHz})$ の PC をもう 1 台用意した .

Point Grey Research 社製のモノクロ CCD カメラ Flea2 FL2-03S2M をビューベースト教示再生のために導入し た ・ビューベースト教示再生では内部パラメータや外部パラメータのキャリブレーションは必要ないことに注意 されたい . また , Imaging Source 社製のモノクロ CCD カメラ DMK 31AF03 を再生結果の評価のためだけに導入 した . 両者のカメラともにIEEE1394のインタフェース経由でPCにつながっている .

\section{2 押し 操作}

手法の検証として , 今回は準静的な押し操作にビューベースト教示再生を適用した . 対象物はロボットのハン ド (図 7) によってゴール位置まで押される . 対象物は $60 \times 30 \times 30 \mathrm{~mm}$ の木製ブロックである. 本手法はビュー 


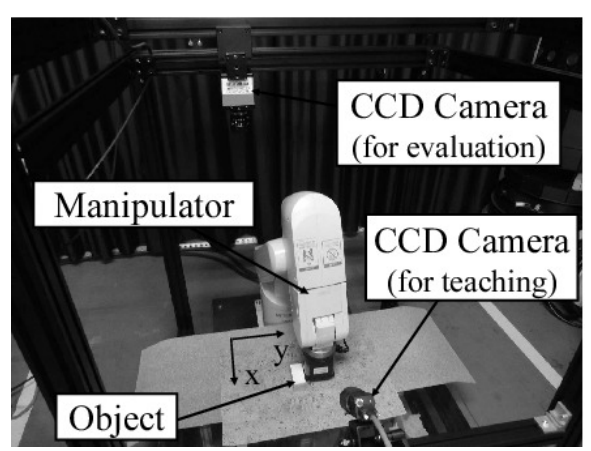

Fig. 6 Experimental Setup

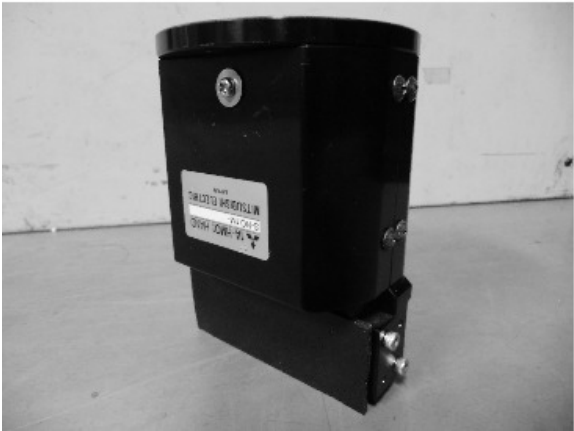

Fig. 7 Hand of Manipulator

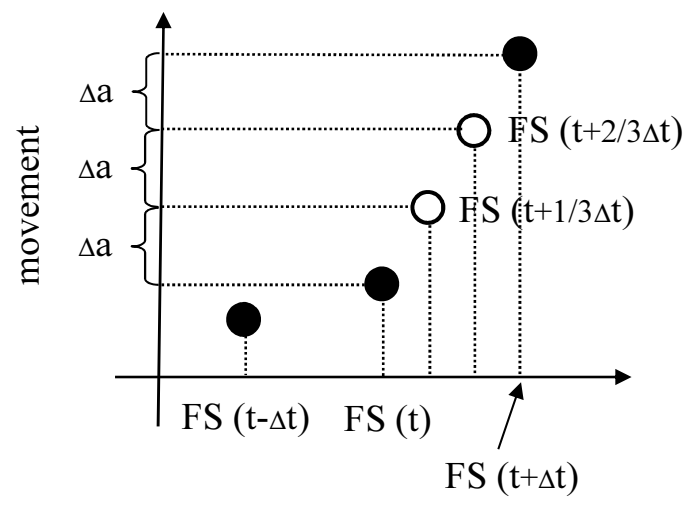

Fig. 8 Image of Interpolation

ベーストであるため，大きさや形といった対象物の情報を知らなくてもよいことに注意されたい .

\section{3 作業の教示}

教示フェーズでは教示者がゲームパッドでロボットのハンドを動かす . ゲームパッドのジョイスティックからの 指令は $x, y, \theta$ 方向の 3 自由度であるため, ロボットのハンドの動きは 3 次元ベクトルで次のように表現される .

$$
\operatorname{Move}(t)=[\Delta x(t), \Delta y(t), \Delta \theta(t)]^{T}
$$

ここで, $\Delta x(t), \Delta y(t), \Delta \theta(t)$ は光れ光れ $x, y, \theta$ 方向のロボットのハンドの移動量である .

ジョイスティックの倒し始めや戻し始めで急激な指令值の変動が生じてしまうことがあるが，ニューラルネット ワークでは炎のような変動を表現するのは難しい，光のため, ジョイスティックからの指令值に対して次式に示す 一次遅れフィルタを導入する.

$$
b(t)=\frac{a(t) \Delta t+T b(t-\Delta t)}{T+\Delta t}
$$

ここで, $a(t), b(t)$ は一次遅れフィルタリング前後の指令值,$T$ は時定数である .これによって指令值の急激な変 動が抑えられている.なお, 本論文では $x, y$ 方向の時定数 $T_{x y}=0.10 \mathrm{~s}, \theta$ 方向の時定数 $T_{\theta}=0.15 \mathrm{~s}, \Delta t=1 / 60 \mathrm{~s}$ と した。

教示の際，カメラ画像と炎の時のロボットのハンドのコンフィグレーション，光れに対応したロボットのハン ドの移動量か記録される . カメラ画像は $640 \times 480$ のグレースケールで， $60 \mathrm{~Hz}$ で取得される . なお，ハンドのコ ンフィグレーションは $x, y, \theta$ 方向の座標 $X(t), Y(t), \Theta(t)$ を用いて次のように表現される .

$$
\operatorname{Config}(t)=[X(t), Y(t), \Theta(t)]^{T}
$$




\section{4 教示データの補間}

一次遅れフィルタを導入することによってジョイスティックによる指令值の飛びをある程度緩和することができ たが，光れでもジョイスティックの倒し始めと戻し始めで指令值の大きな飛びが発生することがある．弚こで，指 令值の飛びが大きい区間に対して教示データの補間を行うことにする.補間については次の評価関数 $\Delta E$ を用いる.

$$
\Delta E=\sqrt{|\Delta(\Delta x)|^{2}+|\Delta(\Delta y)|^{2}+|r \Delta(\Delta \theta)|^{2}}
$$

ここで, $\Delta(\Delta x), \Delta(\Delta y), \Delta(\Delta \theta)$ は $x, y, \theta$ 方向のハンドの移動量の差分,$r$ はハンドの重心から四隅の一つまでの距離 である．補間はこの評価関数 $\Delta E$ があらかじめ設定した閾値 $E_{\mathrm{thre}}$ よりも大きくなった場合に行い，弚の区間前後 の移動量から線形補間する . この補間に当たっては，指令值の飛びの大きさに応じて区間の分割数 $N_{\mathrm{div}}$ を次のよ うに決定する．

$$
N_{\text {div }}=\left\lceil\frac{\Delta E}{E_{\text {thre }}}\right\rceil
$$

ただし, 計算結果は小数以下を切り上げとする .なお, 本論文では $E_{\mathrm{thre}}=0.007 \mathrm{~mm}$ とした .

ここで, 前述の補間について図 8 を用いて説明する . ある時刻 $(t+\Delta t)$ のハンドの移動量が 1 step 前の移動量に 比へて急激に大きくなっている場合，教示時に得られたデータ (黑い点) から線形補間をして人工的な教示デー タ (白い点) を生成する.なお，図 8 の場合では区間の分割数 $N_{\mathrm{div}}=3$ として補間を行なっている.

\section{5 マッピングの獲得}

カメラ画像と光れに対応したロボットのハンドの移動量をマッピングするために , 図 3 に示した三層型のフィー ドフォワード型のニューラルネットワークを用いる .このニューラルネットワークは出力数が 3 , 入力層が 56 $(\mathrm{FS}(t): 50, \operatorname{Config}(t): 3, \operatorname{Move}(t-\Delta t): 3)$ ，隠れ層が 50 である 3 層型ニューラルネットワークを用いる.なお， 入 力の一つである，現在画像の主成分スコア数は上位 50 成分 $(N=50)$ とした . 教示フェーズの画像を再現するだけ であればもっと少ない数でも十分だが, 教示時と異なる条件になった場合の情報量の確保を考え, 再生フェーズ の制御ループが $60 \mathrm{~Hz}$ で動作する範囲内での大きめな値を設定した . ニューラルネットワークの重みはモーメント 因子を 0.9 として BPM により計算する。なお，誤差が収束するか計算時間が 1800 sになるまでBPM を繰り返す，

ここで, ニューラルネットワークの学習成分について考える. 本論文で用いるニューラルネットワークでは出 カにロボットの動き (並進および回転)，入力の一つに現在画像の主成分スコアをとっている．並進と回転は異な

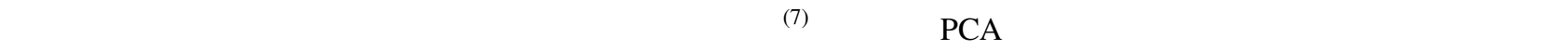
抽出できないことが指摘されている.これはPCA の上位主成分として抽出されるのは教示画像群におけるピクセ ルデータの変化の大きいものであり, ピクセルデータの変化の大きい並進成分の方が回転成分よりも抽出されや すいということを示している. 弚のため, BPMの $\theta$ 方向の誤差関数がより重視されるような重み付けを行うこと にした . 具体的には, 誤差逆伝播法において, 出力層への結合荷重の修正量を求める際の学習率 ${ }^{(10)}$ を, $\theta$ 方向以 外は $1 / 100$ に設定している.

\section{6 再生フェーズ}

再生フェーズでは上位 50 成分の主成分スコアが現在画像から計算される . 主成分スコアの計算には並列スレッ ドでIntel SSE (Streaming SIMD Extensions) を用いており，再生フェーズの制御ループも 60Hz で動作する．また， 作業の終了条件に用いる参照点としてはハンドの先端の四隅の点を用い，閾値は $T_{S}=2.0, T_{H}=2.0 \mathrm{~mm}$ とした .

\section{7 異常判定条件}

異常判定には次の評価関数 $\Delta E_{A}$ を用いる.

$$
\Delta E_{A}=\sqrt{|\Delta X|^{2}+|\Delta Y|^{2}+|r \Delta \Theta|^{2}}
$$

ここで , $\Delta X, \Delta Y, \Delta \Theta$ は図 3 と図 5 の二つのニューラルネットワークから算出される $x, y, \theta$ 方向のロボットのハン ドのコンフィグレーションの差, $r$ はハンドの重心から四隅の一つまでの距離である . 

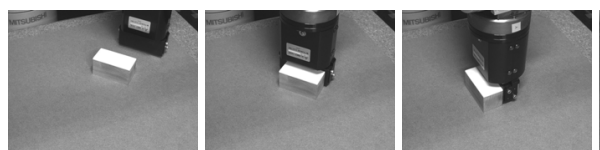

(a) demonstration 1
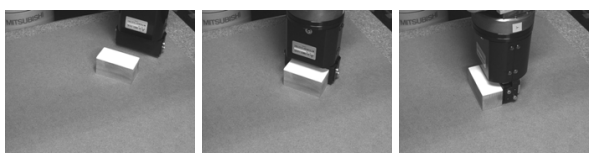

(b) demonstration 2
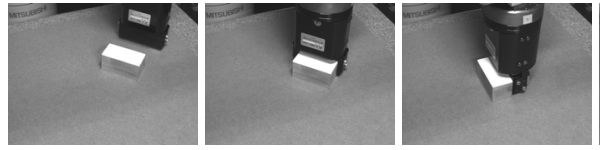

(c) demonstration 3

Fig. 9 Three Demonstrations in Teaching Phase
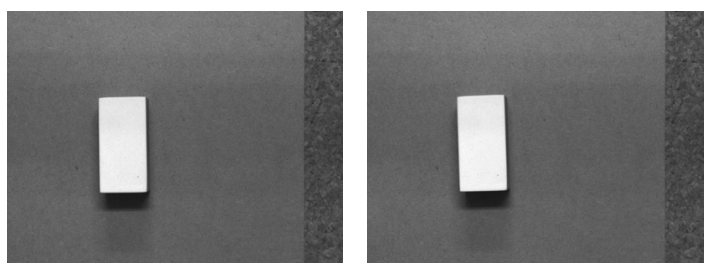

(a) demonstration 1

(b) playback from initial posi- (c) tion of demonstration 1
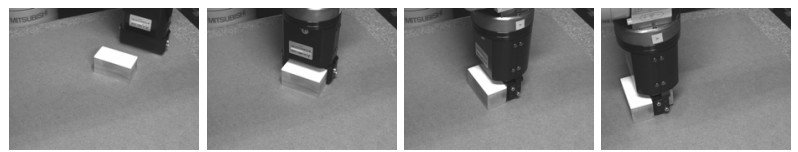

(a) from initial position of demonstration 1

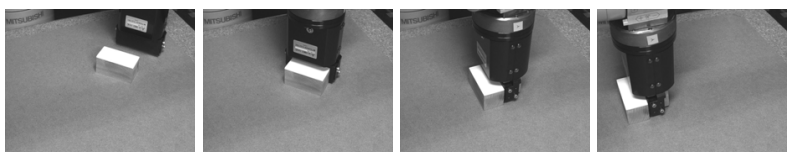

(b) from initial position of demonstration 2
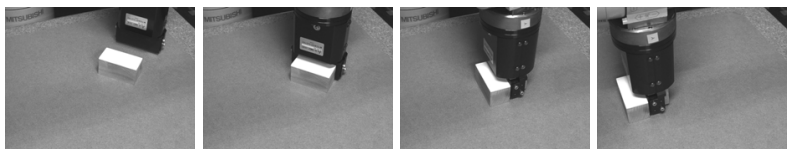

(c) from initial position of demonstration 3

Fig. 10 Playback from Initial Object Positions of Demonstrations
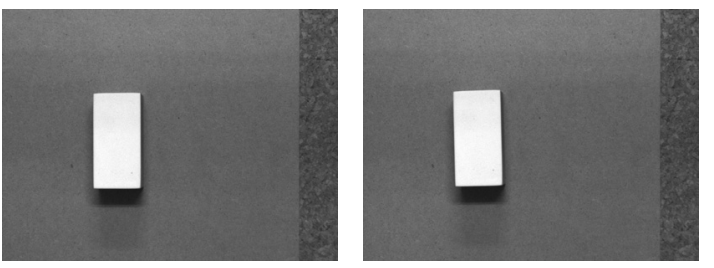

tion of demonstration 2

tion of demonstration 3

Fig. 11 Goal Scenes (Top View)

また，異常判定には次のような条件式（異常判定条件）を定義する．

$\Delta E_{A}>T_{A}$

ここで, $T_{A}$ は閾値である.式 (13) は図 3 と図 5 の二つのニューラルネットワークから算出される 1 step 後のロボッ トのハンドのコンフィグレーションの差が, あらかじめ設定された閾值よりも大きくなった場合, 再生フェーズ においてロボットが予期せぬ状況に陥ったと判断して異常を自動で検知できる．

\section{$7 \cdot 8$ 初期位置の変化に対する実験結果}

図 9 に教示フェーズで行った 3 回の教示を示す. 対象物は一度姿勢を斜めから縦に変えて同じゴール位置まで 運ばれる . 対象物の初期位置は各教示で異なっており，重心位置が光れ艺れ $(275 \mathrm{~mm}, 110 \mathrm{~mm}),(275 \mathrm{~mm}, 120 \mathrm{~mm})$ ， $(285 \mathrm{~mm}, 120 \mathrm{~mm})$ となるようにした . ただし，簡単化のため初期姿勢は一定とした .なお，使用するロボット，カ メラの位置およびハンドの初期位置・姿勢は固定としている . また, 再生フェーズでは異常判定条件は適用して いない .これは, 目標への位置決め誤差が大きくなるような条件においては, 早期に異常判定が発動しマニピュ レーションを停止してしまうことがあり，これが位置決めの定量的評価を困難にするためである .

この実験で教示フェーズにかかったオフラインの計算時間は次の通りである.

- PCA: $951 \mathrm{~s}$

- BPM: $1800 \mathrm{~s}$

なお，教示フェーズでは $640 \times 480$ の画像を 2983 枚取得した . 
7.8.1 教示フェーズと作業条件が同じ場合の再生

図 10 に教示 $1,2,3$ と同じ初期位置からの再生の例を弚れ光れ示す．また，図 11 に，再生終了時の評価用力メ ラの画像を示す．図 9 と比較すると対象物をゴール位置までうまく運べていることがわかる．ここで，ゴール位 置での対象物の位置・姿勢誤差, すなわち教示時と再生時の対象物の四隅の RMS 誤差は上方に設置した評価用力 メラの画像から計算できる. 教示 $1,2,3$ と同じ初期位置からの再生した時の RMS 誤差 (3 回の平均) は光れ光れ 0.90mm, 0.76mm, 1.68mm であった . また，教示 $1,2,3$ と同じ初期位置から従来のティーチングプレイバックを 行ったところ，弚の RMS 誤差 (3 回の平均) は炎れ炎れ $1.19 \mathrm{~mm}, 0.34 \mathrm{~mm}, 1.38 \mathrm{~mm}$ であった .これらの結果から ビューベースト教示再生は , 教示した作業を再現する場合において従来のティーチングプレイバックの代替とな りうる . 従来のティーチングプレイバックの位置誤差は意外に大きかったが , この理由の 1 つとしては対象物と ロボットのハンドとの摩擦が小さく滑りやすいことが挙げられる．

7.8.2 教示フェーズと初期位置が異なる場合の再生

図 12 に各教示の初期位置の中間位置を対象物の初期位置として再生した結果を示す.この状況は教示フェーズ では教えていないが，ニューラルネットワークの汎化能力によって対象物はゴール位置までうまく運ばれている

図 13 に他の位置に対象物の初期位置を設定した場合の再生結果を示す. 図中の色分けされた矩形は, 兴の図心 に対象物の初期位置を設定した際のRMS 誤差を色で表現している．また，○印は 3 回の教示時の初期位置を表し， ×印は停止条件を満たさず搬送が終了しなかった初期位置を示している．7.8.1 項の結果から，従来のティーチン グプレイバックでも誤差が $1 \mathrm{~mm}$ を上回ることがあるので , タスク成功の基準を $\mathrm{RMS}$ 誤差 $2 \mathrm{~mm}$ 以内と設定する . すると, 対象物の初期位置が 3 回の教示の初期位置を結心䕘域内にある場合，ニューラルネットワークによって 得られる補間的な動きによって対象物をゴール位置までうまく運べ，成功していると言える．したがって，想定 される初期位置のばらつきがこの範囲内であれば, 提案するビューベースト教示再生によって作業の教示が実現 できることになる

しかし, 対象物の初期位置を 3 回の教示の初期位置を結引䕘域外にして再生を行うと，再生終了条件を満たせ ずに再生が終了できなかったり，終了できたとしても再生終了時の対象物の RMS 誤差が大きくなってしまうこと が多かった . 具体的には, 再生時に教示時より回転しすぎてしまって再生終了条件を満たせずに再生が終了でき なかったり，対象物に接触する際のハンドの位置が教示の時より $-x$ 方向にズレてしまい，光の結果として再生終 了時の対象物の位置が教示時よりも $+x$ 方向にズレてしまっている．したがって，想定される初期位置のばらつき が広い場合には, 今回の 3 回の教示だけでは不十分であり, 教示回数を増やすなどの対策をとる必要があると考 えられる.

また，今回は異常判定を適用していないが, 異常判定によって再生フェーズで異常が検知された場合には，光 の初期条件での教示を追加してニューラルネットワークを構築し直すことで, さらによい結果が得られると考え られる。

7.9 初期姿勢の変化に対する実験結果

教示フェーズで対象物の初期姿勢を変えて，2 回の教示を行った（図 14,15). 対象物は一度姿勢を斜めから縦 に変えて同じゴール位置まで運ばれる . 対象物の初期姿勢は各教示で異なっているが, 簡単化のため対象物の重 心位置は一定とした．また，使用するロボット，カメラの位置およびハンドの初期位置・姿勢は固定としている

教示フェーズにかかったオフラインの計算時間は PCA が $364 \mathrm{~s}, \mathrm{BPM}$ が $1200 \mathrm{~s}$ であった . なお , 教示フェーズ では $640 \times 480$ の画像を 2298 枚取得している.再生フェーズでは前節と同樣, 異常判定条件は適用していない .

図 16 に各教示の初期姿勢の中間姿勢を初期姿勢として再生した結果を示す .この状況は教示フェーズでは教え ていないが , ニューラルネットワークの汎化能力によって対象物はゴール位置までうまく運ばれている．

図 17 に他の初期姿勢からの再生結果を示す. 図の誤差はゴール位置での対象物の RMS 誤差を示している. 対 象物の初期姿勢が 2 回の教示の初期姿勢を含む一定の範囲内にある場合， ニューラルネットワークによって得ら れる補間的な動きによって対象物をゴール位置までうまく運べた．したがって，想定される初期姿勢のばらつき がこの範囲内であれば，提案するビューベースト教示再生によって作業の教示が実現できることになる． 

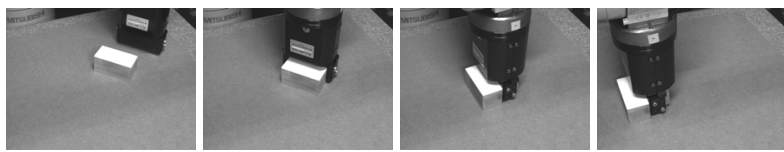

(a) from initial position of demonstration 1 and 2
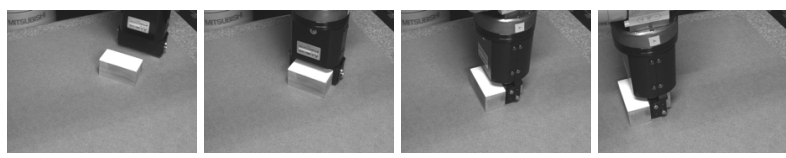

(b) from initial position of demonstration 2 and 3
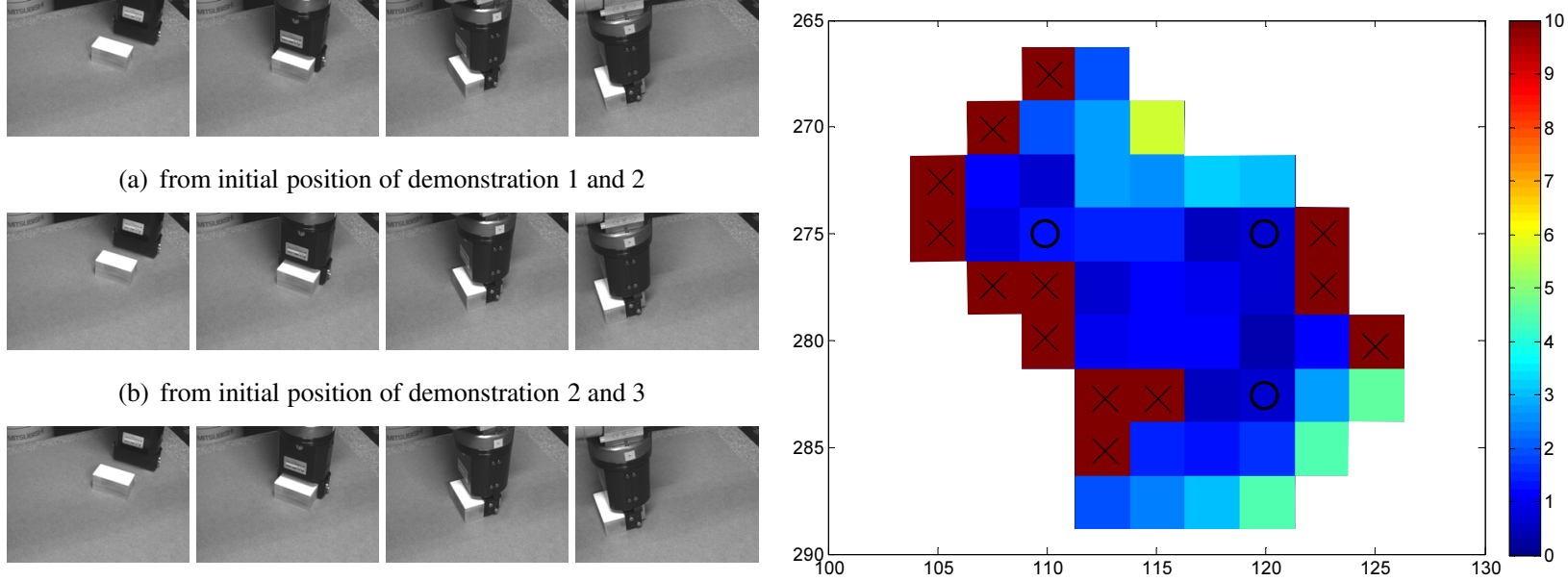

(c) from initial position of demonstration 3 and 1

Fig. 12 Playback from Middle Point of Initial Object Fig. 13 Positions of Demonstrations

RMS Errors [mm] from Various Initial Object Positions
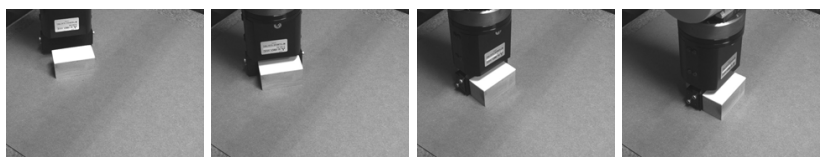

Fig. 14 Demonstration 1 (initial orientation: 37deg)
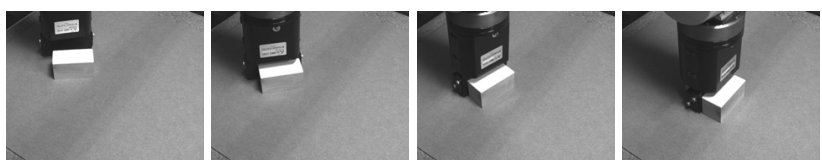

Fig. 15 Demonstration 2 (initial orientation: 45deg)
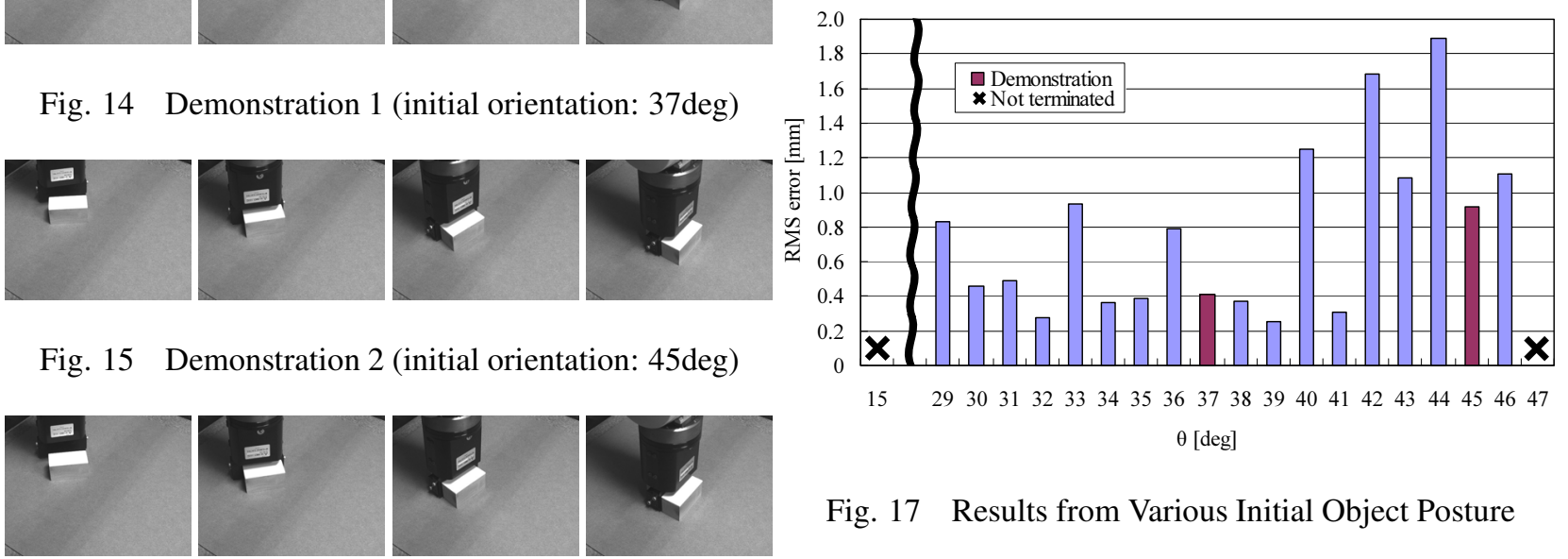

Fig. 16 Playback (initial orientation: 41deg)

\section{$7 \cdot 10$ 異常判定機能の検証}

図 18 のような教示に対して異常判定を用いた例を示す.なお，この例では $T_{A}=25.0 \mathrm{~mm}$ としている.この教示 では，教示フェーズに姿勢を斜めから縦に変えてゴール位置まで運ぶ、ニピュレーションが一回だけ行われている．

まず，異常判定を導入する前の動きについて確認する. 教示と異なる初期位置から再生を行わせると，対象物の 回転が足りず，終了条件を満たせずにロボットが動き続けてしまう（図 19）．これに対して，異常判定を導入し た後の再生結果は図 20 に示す通りであり，対象物の回転が足りない状態で搬送を続けた結果 $\Delta E_{A}$ が大きくなり， 閾值 $T_{A}$ より大きくなった時点で異常だと判定されて再生が緊急停止している.

\section{$7 \cdot 11$ 考察}

$7.8 ， 7.9$ 節よりビューベースト教示再生では, 対象物の初期位置・姿勢が教示時と異なる位置からでも対象物 をゴール位置に運ぶことができた .これは複数回の教示のマニピュレーションが一定の類似性を有するからであ る.つまり，ニューラルネットワークによって得られるロボットの動きは教示のデータから補間できるものに限ら れる. 弚のため, 同じような画像に対して異なる出力を出すような複数回教示が行われると，弚の矛盾に対して ニューラルネットワークがうまく対応できないことが予想される . 

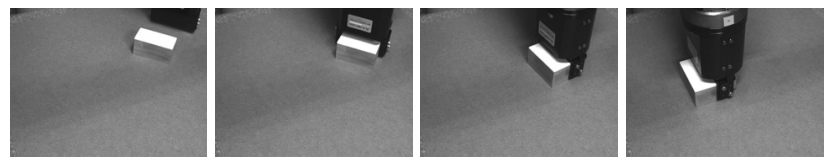

Fig. 18 Demonstration in Teaching Phase
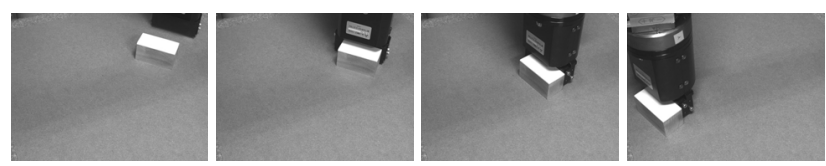

Fig. 19 Failure of Manipulation without Emergency Stop
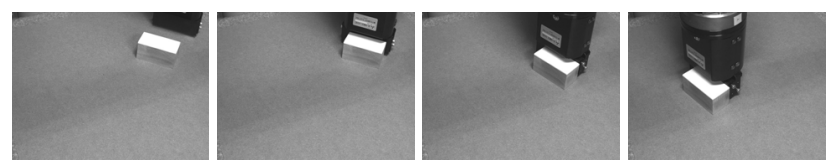

Fig. 20 Failure of Manipulation with Emergency Stop

また , 本手法ではニューラルネットワークの出力を光のままロボットの動きとして利用している関係上, 不連 続な出力変化を必要とするジグザグな経路などを実現させることは難しい .

\section{8. 結論}

本論文では著者らが提案するビューベースト教示再生を実機産業用ロボットにおけるブロックの押し操作に適 用し，対象物を考慮した終了条件の定義や再生フェーズでの異常の自動検知ができるようにした，光の結果，教 示フェーズで複数回教示を行うことにより，対象物の初期位置を教示時と異なる位置としても，一定の範囲内では 対象物をゴール位置までうまく運べることを確認した 。

今後の展望としては，マニピュレーションの精度をどのように高め，また保証していくか，という点が挙げら れる．また，本論文では準静的な押し操作のみを扱ったが，より多樣なタスクへの適用も求められる．仮想環境 上ではあるが, 先行研究 ${ }^{(2)}$ では把持によるマニピュレーションも扱っており，今後実機でも有効性を検証する必要 がある．光のほか，計算の高速化も課題の一つである. 現在 , 再生フェーズの制御ループは $640 \times 480$ の画像を用 いて $60 \mathrm{~Hz} て ゙$ 回っているが, フレームレートや解像度を上げなければならない場合はオンラインの計算をより高速 化することが求められる .

$$
\text { 謝辞 }
$$

本研究は JSPS 科研費 (24560286)の支援を受けたものです .

$$
\text { 文献 }
$$

（1）松本吉央，稲葉雅幸, 井上博允, “ビューベーストアプローチに基づく移動ロボットナビゲーション”, 日本ロボット学会 誌, Vol. 19 , No. 3 (2002) , pp. 506-514 .

(2) Maeda, Y., Nakamura, T., and Watanabe, T., "View-Based Teaching/Playback for Grasp and Graspless Manipulation", Proceedings of International Conference on Advanced Mechatronics, (2010), pp. 75-80.

(3) Billard, A., Calinon, S., Dillman, R., and Schaal, S,, "Robot programming by demonstration," Springer Handbook of Robotics (2008), pp. 1371-1394, Springer.

(4) Argall, B. D., Chernovab, S., Veloso, M., and Browning, B., "A survey of robot learning from demonstration," Robotics and Autonomous Systems, Vol. 57, No. 5 (2009), pp. 469-483.

(5) Shibata, K. and Iida, M., "Acquisition of box pushing by direct-vision-based reinforcement learning", Proceedings of SICE Annual Conference, (2003), pp. 1378-1383. 
(6) 小林祐一, 加藤真人, 細江繁幸, “分解能の調節可能な画像情報からの状態空間の構成”, 日本ロボット学会誌, Vol. 25, No. 5 (2007), pp. 770-778.

(7) Zhang, J., Knoll, A., and Schmidt, R., "A neuro-fuzzy control model for fine-positioning of manipulators", Robotics and Autonomous Systems, Vol. 32, (2000), pp. 101-113.

(8) Zhao, Q., Sun, Z., Sun, F., and Zhu, J., “Appearance-based Robot Visual Servo via a Wavelet Neural Network”, International Journal of Control, Automation, and Systems, Vol. 6, No. 4 (2008), pp. 607-612.

(9) Turk, M. and Pentland A., "Eigenfaces for recognition”, Journal of Cognitive Neuroscience, Vol. 3, No. 1 (1991), pp. 71-86.

(10) 坂和正敏 , 田中雅博 , ニューロコンピューティング入門 (1997), 森北出版. 